\title{
Publications of the Geneva Association
}

\section{ÉTUDES ET DOSSIERS}

Available at the price of SFR 30.-+ postage

Disponible au prix de SFR 30.- + port

Erhältlich zum Preise von SFR 30.-+ Versandkosten

2. (1975) Simulation Model of the Effects of Inflation on Personal and Properts Damage Insurance Companies (J. Belloy, A. Gabus).

3. (1975) Introduction à l'Economie du Risque et de la Sécurité : Première partie: Macro-économie du Risque et de la Sécurité (O. Giarini, H. Loubergé).

4. (1975) A Survey of Insurance and Risk Management Practices in Major European Industrial Companies (R. Damary).

5. (1975) Zur Entwicklung des kollektiven Sparens in vier Ländern bis 1980 (M. Bittner, B. Reitz).

7. (1976) Etude de la Rentabilité des Sociétés d'Assurance Non-Vie en Europe (J. Rosa).

8. (1976) Introduction à l'Economie du Risque et de la Sécurité (Deuxième partie : Textes des Conférences) (R. Barre, H. Bühlmann, O. Giarini, M. Haller, H. Loubergé, J. Rosa).

9. (1976) Barriers to Trade in Insurance and Reinsurance (R. Carter, G. Dickinson).

10. (1976) L'Evolution de la Notion de Responsabilité et ses Conséquences économiques (P. Charpentier).

11. (1976) Banking and Insurance - The Interface (J. E. Maycock, J. Revell).

13. (1977) Zur Entwicklung der Gruppenversicherung und des kollektiven Sparens in der BRD und in Grossbritannient bis 1990 (available also in English) (B. Reitz).

15. (1977) Staat, Sicherheit, Versicherung (M. Haller, W. Ackermann).

16. (1977) International Insurance Transactions and the Balance of Payments (G. M. Dickinson).

17. (1977) A Survey of Consequential Loss Practices in Western Europe with Emphasis on the Chemical Industry (R. Damary).

19. (1978) Staat, Sicherheit, Versicherung - Teil I - Ein internationaler Vergleich (M. Haller, W. Ackermann). 
20. (1977) Staat, Sicherheit, Versicherung - Teil II - Perspektiven (M. Haller, W. Ackermann).

23. (1978) Effets des Réglementations sur la Rentabilité et le Risque des Compagnies d'Assurances Non-Vie (J. Rosa, C. Ferry).

24. (1978) Le troisième Age et l'Assurance (S. Hagemann).

25. (1978) Assicurazione privata contro gli Infortuni - Un Confronto fra le Condizioni di Polizza e le Tariffe italiane, inglesi e francesi (G. de Zuccato).

26. (1979) La Responsabilita civile verso Terzi della attivita imprenditoriali - Analisi comparata Italia e Francia (G. de Zuccato).

27. (1978) European Fire Costs - The Wasteful Statistical Gap (T. Wilmot).

28. (1978) Les Fondements de la Théorie économique du Risque et de l'Assurance (H. Loubergé).

29. (1979) The Insurance Game - A Business Decision Game Based upon a Simulation of an Insurance Market (K. Hansen).

30. (1979) La Formation en Economie du Risque et de la Sécurité des Etudiants en Médecine, Elèves Ingénieurs, et Etudiants en Architecture : une enquête préliminaire (P. Charpentier).

31. (1979) La Situazione e le Prospettive del Mercato delle Assicurazioni collettive in Italia (Group Insurance in Italy) Vol. I (A. Martelli).

32. (1979) La Situazione e le Prospettive del Mercato delle Assicurazioni collettive in Italia (Group Insurance in Italy) Vol. II (A. Martelli).

33. (1979) Insurance Cycles : Cycles in Insurance: A Review of Past Researches and Proposals for Further Studies (G. de Wit) ; Le Développement de l'Assurance et son Environnement Economique (A. Krieff) ; Insurance Cycles : An Italian Experience (C. Angela Mormino) ; Elements of Loss Development : Trends, Business Cycles and Fortuitous Events (E. Helten); Functional Relations between General Economic Indicators, Premium Income and Costs of Damages in Different Insurance Sectors (F. Becker).

34. (1979) Recherche sur les Risques de Pertes indirectes induites par les Systèmes informatiques (A. George).

35. (1980) Les Services complémentaires à l'Assurance - 1 ${ }^{\text {re }}$ partie - Insurance Related Services - part 1 (CAPA).

36. (1980) Die Chancen der Versicherungswirtschaft beim dritten Alter (in Deutschland, Frankreich und in der Schweiz) Troisième Age et Assurance (A. Vernay, S. Hagemann).

37. (1980) The Economic Significance of Insurance in an International Perspective Case Studies of Egypt, Kenya and Norway - Part I (R. Carter).

39. (1980) The Non-Underwriting Activities of the European Insurance Industry Insurance Related Services - Part II (R. Damary).

41. (1980) ASIR Model - The Imides System Demonstration Run (L. Galitz). 
42. (1980) World Fire Costs and their Economic Relevance - A Dossier of the International Fire Costs Seminar in Geneva.

44. (1980) Crime and Insurance (Risk Research Group).

45. (1981) World Fire Costs and their Economic Relevance - Part 2 - A Dossier of the International Fire Costs Seminar in Geneva.

46. (1981) Sources of Statistics : Finland, Ireland, Italy, Spain, United Kingdom, Greece (R. Carter).

48. (1981) La Capitalisation a-t-elle un Avenir en France ?(D. Kessler, D. Strauss-Kahn).

49. (1981) The Economic Significance of Insurance in an International Perspective Part II (G. Dickinson, A. Smith).

50. (1981) A Study of Recall Practice among Manufacturers of Consumer Products (Technomic consultants).

51. (1981) Critical Analysis into the Validity of the National Accounting for the Evaluation of the Services Performed by the Insurance Sector (L. Van den Berghe).

52. (1981) The ASIR System (User's Manual) (M. Brown, L. Galitz).

55. (1982) A Stochastic Simulation Model for Reinsurance Decision Making by Ceding Companies (Y. Roy).

57. (1982) The ASIR System (Advanced Simulation of Insurance and Reinsurance), User's Manual Updating to "Etudes et Dossiers" no 52.

58. (1982) Facing Risk in Modern Societies and Economies - Eagle Lodge (Philadelphia) General Assembly of the Geneva Association, July 1982 : L'Etat et la Demande de Sécurité dans les Sociétés Contemporaines (R. Barre); Trade in Services and the World Economy (R. Askew); Investment Management in an Inflationary World (H. Mast); The Problematique of the Enterprise Today (H. Thiemann); World Disorder and the Future of Enterprise : Summary of a Report to be submitted to the Club of Rome (H. Perlmutter) ; Social Audit : Questions to Corporate Managers (Business International); Country Risk : Experiences (Business International).

59. (1982) Strategic Planning for Insurance - Vol. III - Strategic Management and Organisational Design : Organisational Design with Reference to Insurance Companies (H. van Gelder); Winning the Competitive Battle of the 90ies (M. Muth).

60. (1982) Strategic Planning for Insurance - Vol. IV - Planning at the Company's Level: The Experience of Allstate Insurance Company (J. Gragnola); Corporate Reserving and Profit Models (F. Doyle); The Requirement for Solidity and Equitable Rating (H. Bohman); The Valuation of Outstanding Claims with particular Reference to experience Rating (D. Reid) ; Planning in Reinsurance (F. Guaschi) ; Coping with Fluctuations due to Catastrophe and Large Claims (E. Straub).

61. (1982) Strategic Planning for Insurance - Vol. II - Planning at the Country Level : USA, Spain, France, U.K. : Strategic Planning in the U.S. Property-Liability Insurance Industry (J. Cummins, C. Aylor); The Strategic Planning of the 
Spanish Insurance (J. Serra-Santamans); Corporate Planning in the U.K. Insurance Industry (D. Martin); Insurance and the Future of the Automobile in France (J. Gutman).

62. (1982) Strategic Planning in Insurance - Vol. I - L'Etat de la Planification Stratégique dans l'Industrie Européenne Version française (available also in English) (Ch. Grosjean).

63. (1982) Strategic Planning for Insurance - Vol. V - Models for Insurance Planning : The ASIR Model (L. Galitz) ; A Stochastic Simulation Model for Reinsurance Decision-Making by Ceding Companies (Y. Roy) ; Econometric Forecasting of Property-Liability Insurance Paid Claim Costs (D. Cummins, S. Harrington).

64. (1983) Strategic Planning for Insurance - Vol. VI - Economic Analysis of Insurance: The determination of Fair Profits for the Property-Liability Insurance Firm (A. Kraus, S. Ross); Determining an Appropriate Level of Capital for a Non-Life Insurance Company (G. Dickinson, L. Roberts); A Practical Approach to Measuring the Distribution of Total Annual Claims (A. Paulson, N. Faris).

65. (1983) Strategic Planning for Insurance - Vol. III - Planning in Industry, Banks and Brokers - Vol. VIII - Planning in the Australian Insurance: Introduction to Planning (R. Carter); Strategic Planning in Union Carbide Corporation (G. McNeill) ; Corporate Planning in the Australian Insurance Industry (E. Sharp).

66. (1983) The ASIR System - Second Updating to "Etudes et Dossiers" 52 (M. Brown, L. Galitz).

67. (1983) International Concepts in Fire Protection (P. Schaenman)..

69. (1983) World Fire Costs and their Economic Relevance, First Meeting of the World Fire Statistics Centre (T. Wilmot).

70. (1983) La Valeur d'une Vie humaine (E. S. Kirschen).

71. (1983) Social Security, Public Deficit and Saving: The Economic Environment for the Italian Private Insurance (Summary); Sicurezza Sociale, Disavanzo Pubblico : Il Caso Italiano (L. Vitali).

72. (1983) Product Recall and Associated Insurance Issues : Papers from a Two-Days Seminar by the Geneva Association.

73. (1983) Risk and Insurance Economics Education for Engineers : Proceedings of the first International Seminar, London, June 1983: The Development of Risk Management Education (C. Crockford); The Development of a MultiDisciplinary Degree in Risk Management (G. Dickson); The Role of Safety and its Financial Implications in the Education of Undergraduate Engineers (S. Tailby); The Management of the Goals of Engineering Education Project (GEEP) at Leicester Polytechnic (G. Beuret); A Report of the Survey Undertaken by the Centre for Insurance Research on Risk Management and Insurance Economics Teaching to Engineers in the UK, Scandinavia and the Netherlands (D. Sutherland).

74. (1983) Space Projects Study and Coverage of Associated Risks - Part I : Inventory of Space Projects (P. Blassel). 
75. (1983) Facing Financial, Economic and Political Risks, Conference Panel by R. Barre, U. Colombo, A. King, P. W. McCracken, H. Schlesinger, at the occasion of the tenth General Assembly of the Geneva Association.

76. (1984) The ASIR System (Advanced Simulation of Insurance and Reinsurance), User's Manual - Revision of Etudes et Dossiers 52 (M. Brown, L. Galitz).

77. (1984) Natural Disasters and Insurance Part IV - Proceedings of the first Meeting of the International Working Group : National Flood Insurance Program, Flood Insurance Manual Revision Rates and Rules (F. Reilly); Seismic Risk for the Largest Cities of the World (V. Keilis-Borok, T. Kronrod); An Insurance-Oriented Pilot Estimation of Seismic Risk for Rural Dwellings in Georgia (V. I. Keilis-Borok); The Role of Education and Awareness of Population in Risk Mitigation (S. Metreveli).

78. (1984) A Guide to the ASIR Model (M. Brown).

79. (1984) The Teaching of Risk and Insurance Economics for Engineers in the U.K., the Scandinavian Countries and Holland (Vol. I) (D. Sutherland).

80. (1984) The Teaching of Risk and Insurance Economics for Engineers (Vol. II) (D. Sutherland).

\section{PUBLICATIONS D'ÉTUdes DE L'ASSOCIATION DE GENÈVE PAR DES INSTITUTS UNIVERSITAIRES \\ Publications of the Geneva Association researches by University Institutes \\ Veröffentlichungen von Studien der Genfer Vereinigung durch Universitäts-Institute}

- Institut Universitaire d'Etudes Européennes, Genève : L'Enseignement de l'Economie du Risque et de l'Assurance en Europe 1976/77 (H. Loubergé), 144 p., novembre 1976.

- Institut für Versicherungswirtschaft der Hochschule St. Gallen : Versicherungs- und Risikowirtschaftslehre in Europa 1977/78 (H. Loubergé, H. Kaplanek), 262 p., juin 1978.

- University of Nottingham, Department of Economics : Survey of Risk and Insurance Teaching in Europe 1979/80 (R. L. Carter, P. Stark), 255 p., 1981.

LIVRES PUBLIÉS AVEC LA CONTRIBUTION DE L'ASSOCIATION DE GENÈVE Books published with the contribution of the Geneva Association Bücher herausgegeben mit der Unterstützung der Genfer Vereinigung

- Les Nations Unies et l'Assurance-Réassurance (R. Krommenacker), Librairie Générale de Droit et de Jurisprudence, Paris 1975, 215 p. 
- Die Betriebliche Alterversorgung (E. Riedlbauer), Verlag Versicherugswirtschaft e.V., Karlsruhe 1975, 112 p.

- Trends in Life Insurance and Related Saving Schemes (S. Wynn), Associated Business Programmes, London 1975, $120 \mathrm{p}$.

- Alterssicherung und Einkommensverteilung (W. Schmähl), Verlag J. C. B. Mohr, Tübingen $1977,480 \mathrm{p}$.

- The Effect of Transaction Costs on the Demand for Life Insurance (D. Moffet), Université Laval, Québec, Canada 1977, 111 p.

- Insurance Management in Africa (J. O. Irukwu), The Caxton Press (West Africa) Limited, Ibadan 1977, 425 p.

- Theorie des Versicherungsgleichgewichts (R. Eisen), Duncker \& Humbolt, Berlin 1978, $183 \mathrm{p}$.

- Selbstbeteiligung unter Risikotheoretischen Aspekten (H. P. Sterk), Verlag Versicherungswirtschaft e.V., Karlsruhe 1979, 278 p.

- Economie et Finance de l'Assurance et de la Réassurance (H. Loubergé), Editions Dalloz 1980.

- Reinsurance in the third World (J. O. Irukwu), The Caxton Press (West Africa) Limited, Ibadan 1980.

- L'Epargne et la Retraite - L'Avenir des Retraites préfinancées (D. Kessler et D. Strauss-Kahn), Editions Economica, Paris 1982, 183 p.

- The Value of Life and Safety, Proceedings of a Conference held by the "Geneva Association ", M. W. Jones-Lee, Editor, North Holland, 1982, 309 p.

- Risks at Sea - Amsterdam Insurance and Maritime Europe 1766-1780 (F. C. Spooner), Cambridge University Press 1983, 320 p.

\section{AUTRES BULLETINS D'INFORMATION Other Information Bulletins}

(gratuits sur demande - free on request)

- Lettres d'Information (Summary of the activities of the Geneva Association - Résumés des activités de l'Association de Genève).

- Newsletter, of the European Group of Risk and Insurance Economists.

- Bulletin, of the World Fire Statistics Centre.

- Progres Newsletter, informations on the Programmes of Research on the Services Economy.

- ASIR News, informations on computer simulations of insurance reinsurance, risk management, vulnerability and financial management.

- Risk Management Studies Bulletin. 


\section{THE GENEVA PAPERS ON RISK AND INSURANCE}

\section{Les Cahiers de Genève / Die Genfer Hefte}

(Each issue / chaque numéro / Jede Ausgabe : SFR 30.-)

1. (1976) A Model for Measuring the Impact of Inflation on Motor Insurance Business.

2. (1976) The Management of Risk and Insurance : The Changing Face of Risk Management (G. N. Crockford); Les Objectifs du Risk Management (M. Haller); A Survey of the Practice of Risk Management in West Europe Companies (R. Damary).

3. (1976) Nature et Importance des Pertes Economiques dans l'Utilisation de l'Informatique en Europe en 1988 (photocopie).

4. (1977) The Teaching of Risk and Insurance Economics in Europe (H. Loubergé).

5. (1977) Théorie Economique du Risque et de l'Assurance : Theorie des Versicherungsunternehmens (D. Farny); La Demande d'Assurance-Vie (C. Ferry); La Demande d'Assurance Non-Vie (J. J. Rosa).

6. (1977) Economic Theory of Risk and Insurance : Optimal Life Insurance (K. Borch); International Insurance Transactions and the Balance of Payments (G. M. Dickinson) ; Economics, Vulnerability and the Diminishing Returns of Technology (O. Giarini) ; Business Cycles and Insurance (E. Helten) ; Insurance in the National Accounts: A case-Study of France (L. Van den Berghe).

7. (1978) Risks in Modern Society : New Dimensions of Risks (M. Haller); Trends of Risk and Security (R. Ellsworth); The Investments of Insurance Companies (M. Einaudi) ; Industrial Management Flexibility (F. Thomée); Security as a Service (H. Braunschweiler).

8. (1978) First Annual Lecture : New Developments in the Theory of Risk-Allocation (K. Arrow).

9. (1978) Economic Problems in Risk Management : Risk, Uncertainty and Economic Futures (H. Henderson); Responsabilité du Fait des Produits (P. Charpentier); Consequential Loss Practices in Western Europe (R. Damary); L'Assurance dans les Relations Economiques Internationales (L. Kramar).

10. (1978) Social Security and Insurance : State, Security and Insurance (W. Ackermann); Social Security Versus Private Saving and Insurance (G. von Fürstenberg); Group Insurance and Collective Saving in the Federal Republic of Germany and in Great Britain (B. Reitz); La Prévoyance dans l'Economie italienne (G. Petrilli); The Expansion of Social Security in Italy (L. Vitali); Soziale Sicherheit und Staatsfinanzen (A. Radner); Document : Problems of Social Security under Economic Recession and Inflation.

11. (1979) Economic Theory of Risk and Insurance: The Risk-Sharing Problem (D. Moffet); A Mathematical Model of Insurance Business (H. Bohman); Simulation of an Automobile Portfolio (F. Corlier, J. Lemaire) ; Long Term Investment in an Insurance Company (E. Prieto Perez); Reinsurers' Investment and Underwriting Portfolios and the Exchange Rates Risk (Y. Kahane). 
12. (1979) Second Annual Lecture - Human Capital and Risk-Bearing (J. H. Drèze).

13. (1979) Studies in Risk Management (photocopy): The Nature and Importance of Economic Losses Due to the Utilisation of Containers in the Transportation Systems (J. P. Pezier); Les Risques de Pertes indirectes induites par les Systemes informatiques (A. George); Risk and Indirect Losses Due to the Utilisation of Computerized Systems (English Summary); European Fire Costs : the Wasteful Statistical Gap (T. Wilmot).

14. (1979) Essays in Insurance Economics : Solidity, Leverage and the Regulation of Insurance companies (Y. Kahane); Reinsurance and Foreign Exchange Risk (H. Loubergé); General Economic Indicators, Premium Income and Claims Costs in Different Insurance Sectors (F. Becker); Investment Behaviour of British Life Offices 1963-1977 (J. C. Dodds); Economists in the Insurance Industry (W. Zajdlic).

15. (1980) Third Annual Lecture : The Effect of Social Security on Saving (M. Feldstein).

16. (1980) Risque et Vulnérabilité dans les Economies européennes: Thoughts on the Policy of Detente in Europe (B. Kreisky); Le Système Monétaire Européen (R. Triffin) ; L'Assurance et l'Intégration Monétaire Européenne (F. Padoa); Economics and Risk (U. Nieto de Alba).

17. (1980) The Economic Theory of Risk and Insurance: The Demand for UK Ordinary Life Insurance (S. Diacon); The Demand for Non-Life Insurance (A. Falciglia); The New "Schwankungsrückstellung" in Annual Statements of German Insurers (W. Karten); Portfolio Adjustment in a Reinsurance Market (N. Doherty); L'Accroissement de Risque : Théorie et Application a la Production en Incertitude (L. Eeckhoudt); Deductibles from a RiskTheoretical Point of View (H. P. Sterk).

18. (1981) Social Security, Retirement and Insurance: Social Security and Saving (D. Kessler, A. Masson, D. Strauss-Kahn); Real Rates of Return and Pension Funding - Some Preliminary Considerations (R. Hemming); Capital Investment and Saving (F. Schott); Le Troisième Age: Problemes et Perspectives (S. Hagemann).

19. (1981) La Marge de Solvabilité : La Marge de Solvabilité (A. Gabus); Solvency Margin and its Effects on Competition - English Summary.

20. (1981) Fourth Annual Lecture : The Three Markets for Private Insurance (K. Borch).

21. (1981) Economic Theory of Risk and Insurance : Underinsurance on a Portfolio of Property Exposures in an Inflationary Environment (G. Dickinson, L. Roberts) ; Information and Observability (R. Eisen) ; Les Opérations des Compagnies d'Assurance IARD (J. Outreville); Stochastic Dominance: An Application to the Insurance Portfolio Decision (D. Gandhi); Theoretical Concepts of Insurance Production (W. Müller); The Activity of Insurance Business and its Relevance for a General Reassessment of Economic Theory (O. Giarini).

22. (1982) Studies in Risk Management (I): Risk Management Under Changing Economic Conditions (R. Carter) ; Développement Economique et Croissance 